\title{
KAJIAN POTENSI DAN STRATEGI PENGEMBANGAN WISATA ALAM DI KAWASAN HUTAN DENGAN TUJUAN KHUSUS (KHDTK) GUNUNG BROMO
}

\author{
Study Of Potential And Development Strategy Nature-Based Tourism In Forest \\ Area With Special Purposes (Khdtk) Gunung Bromo
}

\section{Dwi Apriyanto dan Kusnandar}

\author{
Program Studi Pengelolaan Hutan, Fakultas Pertanian, Universitas Sebelas Maret, \\ Program Studi Agribisnis, Fakultas Pertanian, Universitas Sebelas Maret \\ Jl. Ir Sutami No.36 A, Kec. Jebres, Kota Surakarta, Jawa Tengah 57126 \\ Email : dwiapriyanto52@gmail.com
}

Direvisi : 08/02/2020, Diterbitkan 02/03/2020

\begin{abstract}
KHDTK Gunung Bromo Karanganyar is a state forest area whose management was handed over to Sebelas Maret University starting in 2018. The study of the potential and strategy for developing nature-based tourism is very much needed by managers to support sustainable forest management. This study aims to determine visitor ratings, analyze ADO-ODTWA, and formulate strategies for developing nature-based tourism in the KHDTK Gunung Bromo. Data was collected through structured interviews with 40 visitors, field observations, and in-depth interviews with managers, stakeholders and the community. Potential data were analyzed with ADO-ODTWA Dirjen PHKA 2003 and SWOT (Strength, Weakness, Opportunities, Threats) analysis to determine the right strategy in nature-based tourism management. The results showed the visitor's assessment of access to the location was considered good (40\%) and very good (17\%); cleanliness is considered sufficient (70\%) and good (20\%); infrastructure is considered not good (60\%); the natural scenery is considered good (63\%) and very good (20\%). The result of the ADO-ODTWA potential value is 6.040 medium value classifications. The strategies for developing nature-based tourism in the KHDTK Gunung Bromo are: maintain high forest resource potential as a tourist attraction; developing tourism products that have competitiveness; management collaboration with investors in line with ecotourism; and conducting intensive promotional activities.
\end{abstract}

Keywords; KHDTK; Ecotourism; Strategy; Nature Tourism

\begin{abstract}
ABSTRAK
KHDTK Gunung Bromo Karanganyar adalah kawasan hutan negara yang pengelolaanya diserahkan kepada Universitas Sebelas Maret mulai tahun 2018. Kajian potensi dan strategi pengembangan wisata alam sangat diperlukan oleh pengelola untuk mendukung pengelolaan hutan yang lestari. Penelitian ini bertujuan untuk mengetahui penilaian pengunjung wisata terhadap obyek dan daya tarik wisata, menganalisis Daerah Operasi Obyek dan Daya Tarik Wisata Alam (ADO-ODTWA), dan merumuskan strategi pengembangan wisata alam di KHDTK Gunung Bromo. Data dikumpulkan melalui
\end{abstract}


wawancara terstruktur kepada 40 orang pengunjung, observasi di lapangan, dan wawancara mendalam terhadap pengelola, akademisi, stakeholder dan masyarakat. Data potensi dianalisis dengan pedoman Analisis Daerah Operasi - Obyek dan Daya Tarik Wisata Alam (ADO-ODTWA) Dirjen PHKA tahun 2003 dan analisis SWOT (Strength, Weakness, Opportunities, Threats) untuk menentukan strategi yang tepat dalam pengelolaan wisata alam. Hasil penelitian menunjukan penilain pengunjung terhadap akses menuju lokasi dinilai baik (40\%) dan sangat baik (17\%); tingkat kebersihan dinilai cukup $(70 \%)$ dan baik $(20 \%)$; sarana prasarana dinilai tidak baik $(60 \%)$; keindahan alam dinilai baik (63\%) dan sangat baik (20\%). Hasil nilai potensi ADO-ODTWA sebesar 6.040 termasuk klasifikasi nilai sedang. Adapun strategi pengembangan wisata alam di KHDTK Gunung Bromo yaitu: mempertahankan potensi sumber daya hutan yang tinggi sebagai daya tarik wisata; mengembangkan produk wisata yang memiliki daya saing; kolaborasi pengelolaan dengan investor yang sejalan dengan ekowisata; dan melakukan kegiatan promosi secara intensif.

Kata kunci; KHDTK; Ekowisata; Strategi; Wisata Alam

\section{PENDAHULUAN}

KHDTK Gunung Bromo merupakan kawasan hutan yang diserah-terimakan pengelolaannya dari Kementrian Lingkungan Hidup dan Kehutanan (KLHK) kepada UNS pada tahun 2018. Pengelolaan kawasan hutan seluas 122,78 ha oleh UNS tersebut didasarkan pada Surat Keputusan (SK) Menteri Lingkungan Hidup dan Kehutanan No.177/MENLHK/SETJEN/PLA.0/4/2018 Tentang KHDTK (Kusumastuti 2018; UNS 2018). Keberadaan KHDTK diharapkan dapat memberikan manfaat yang luas kepada masyarakat melalui penelitian dan pengembangan kehutanan, pendidikan dan pelatihan kehutanan.

Menurut Nugroho (2017) salah satu tantangan bagi pengelola KHDTK dalam melaksanakan kewajiban pengelolaan adalah masalah pembiayaan dalam melaksanakan kegiatan pengelolaan KHDTK. Pengelola dapat memanfaatkan potensi sumber daya hutan secara berkelanjutan untuk pembiayaan pengelolaan KHDTK secara mandiri. Pendanaan secara mandiri perlu dilaksanakan karena pengelola tidak mendapatkan support pendanaan dari pemerintah. Pendanaan tersebut digunakan dalam pengelolaan KHDTK serta menutupi biaya operasional pengelolaan.

Pengusahaan wisata alam atau ekowisata di KHDTK Gunung Bromo merupakan salah satu kegiatan yang dapat dilakukan sebagai sumber pendanaan dalam pengelolaan KHDTK. Ekowisata merupakan pengelolaan alam dan budaya masyarakat dengan pendekatan konservasi yang menjamin kelestarian dan kesejahteraan (Nurfatriani \& Efida 2003). Ekowisata tidak hanya diyakini dapat mendorong pertumbuhan ekonomi secara regional maupun lokal untuk peningkatan kesejahteraan masyarakat, namun juga kelestarian sumberdaya alam dan keanekaragaman hayati sebagai obyek dan daya tarik wisata. Berdasarkan penelitian Karyono dan Subarudi (2001) menunjukan bahwa produk jasa wisata alam sebagai nilai tambah dari produk kayu mempunyai nilai yang jauh lebih besar (11 kali lipat) dari produk kayu itu sendiri. Oleh karena itu kajian potensi dan perumusan strategi pengembangan wisata alam di KHDTK Gunung Bromo penting untuk dilakukan bagi pemanfaatan yang berkelanjutan. Penelitian ini bertujuan untuk mengetahui penilaian pengunjung wisata terhadap obyek dan daya tarik wisata, menganalisis Daerah Operasi Obyek dan Daya Tarik Wisata Alam (ADO-ODTWA), dan merumuskan strategi pengembangan wisata alam di KHDTK Gunung Bromo. 


\section{METODE}

Penelitian dilkasanakan di KHDTK Gunung Bromo yang terletak di Kelurahan Gedong, Kecamatan Karanganyar, Kabupaten Karanganayar, Jawa Tengah. Kawasan KHDTK Gunung bromo merupakan kawasan hutan yang sebelumnya dikelola oleh Perum Perhutani kemudian sejak tahun 2018 kawasan tersebut dikelola oleh Universitas Sebelas Maret. Penelitian dilaksanakan selama Juli-September 2019. Alat dan bahan yang digunakan dalam penelitian yaitu alat tulis, kamera, GPS receiver, dan kuesioner. Data penilaian pengunjung terhadap KHDTK Gunung Bromo diperoleh dari kuesioner pengunjung sebanyak 40 responden yang dipilih secara accidental sampling (Kumar 1999) dengan pendekatan non-probability sampling, yaitu pengunjung yang datang dan bersedia dijadikan responden. Analisis potensi obyek daya tarik wisata alam menggunakan sistem nilai skoring dan pembobotan berdasarkan pedoman ADO-ODTWA Dirjen PHKA tahun 2003. Kriteria yang dipakai sebagai dasar penilaian meliputi: daya tarik obyek wisata darat, potensi pasar, kadar hubungan/aksesibilitas, kondisi sekitar kawasan, pengelolaan dan pelayanan, iklim, akomodasi, sarana dan prasarana penunjang, ketersediaan air bersih, hubungan dengan obyek wisata di sekitarnya, keamanan, daya dukung kawasan, pengaturan pengunjung, dan pemasaran. Strategi pengembangan wisata alam di KHDTK Gunung Bromo dirumuskan menggunakan analisis SWOT (Rangkuti 2000, Fahmi 2015). Responden analisis SWOT dipilih secara purposif sampling, responden terpilih sebanyak 4 orang peniliti dan pengelolaa KHDTK Gunung Bromo. Responden dipilih karena responden dianggap mengetahui dan memahami kondisi lingkungan internal maupun eksternal KHDTK Gunung Bromo.

\section{HASIL dan PEMBAHASAN}

\section{A. Penilaian Pengunjung Terhadap KHDTK Gunung Bromo}

Data penilain pengunjung terhadap KHDTK Gunung Bromo dilakukan untuk mengetahui persepsi pengunjung terhadap produk wisata di kawasan sebagai informasi dalam menyusun rencana pengelolaan. Responden pengunjung KHDTK Gunung bromo sebanyak 40 orang dengan karakteristik responden sebagaimana pada Tabel 1. Sebagian besar pengunjung wisata di KHDTK Gunung Bromo adalah usia muda. Menurut Korah (1995), kelompok usia muda memilki waktu luang yang relatif lebih banyak bila dibandingkan dengan lainnya. Kelompok ini juga memiliki kecenderungan memanfaatkan waktu luangnya untuk bepergian ke tempat-tempat wisata alam.

Tabel 1. Karakteristik Pengunjung KHDTK Gunung Bromo Table 1. Characteristics of KHDTK Gunung Bromo visitors

\begin{tabular}{|c|c|c|c|c|c|}
\hline Keterangan & Jumlah & $\%$ & Keterangan & Jumlah & $\%$ \\
\hline 1. Jenis kelamin & & & 4. Status & & \\
\hline Laki-laki & 30 & $60 \%$ & Menikah & 9 & $23 \%$ \\
\hline Perempuan & 10 & $20 \%$ & Lajang & 31 & $77 \%$ \\
\hline 2. Usia & & & 5. Pekerjaan & & \\
\hline Remaja (12-25 th) & 32 & $64 \%$ & PNS & 1 & $2 \%$ \\
\hline Dewasa awal (26-45 th) & 4 & $8 \%$ & Mahasiswa/Pelajar & 21 & $42 \%$ \\
\hline Dewasa akhir (46-65 th) & 4 & $8 \%$ & Pegawai Swasta & 8 & $16 \%$ \\
\hline
\end{tabular}


3. Pendidikan

SD

SMP

SMA

Akademi (D1-D4)

Universitas (S1)

Universitas (S2-S3)
Wirausahawan

Tidak bekerja

6. Tingkat pendapatan bulanan

Rendah (< Rp 1.800.000)

Sedang (Rp 1.800.000 - 4.800.000)

Tinggi (> Rp 4.800.000)
$7 \quad 14 \%$

$36 \%$

$28 \quad 56 \%$

$10 \quad 20 \%$

$24 \%$

Hasil penilaian pengunjung terhadap Wisata Alam di KHDTK Gunung Bromo disajikan pada Gambar 1. Mayoritas pengunjung menilai akses menuju tempat wisata baik atau sangat baik hal ini karena letak lokasi yang strategis dan kondisi jalan yang baik. Sebagian besar pengunjung merasa akses untuk mendapatkan informasi tentang KHDTK Gunung Bromo tidak baik atau sulit diperoleh hal ini karena pengelola belum melakukan publikasi secara intensif di media online.

Sarana dan prasarana dinilai pengunjung tidak baik (60\%). Peningkatan sarana dan prasarana harus menjadi perhatian utama pengelola kawasan. Pentingnya ketersediaan fasilitas yang baik untuk wisatawan dikarenakan adanya tingkat ketertarikan terhadap suatu destinasi dan akan dipengaruhi oleh ketersediaan fasilitas yang ditawarkan (Vengesayi 2003). Mayoritas pengunjung menilai keindahan alam di lokasi sangat baik (20\%) dan baik (63\%).

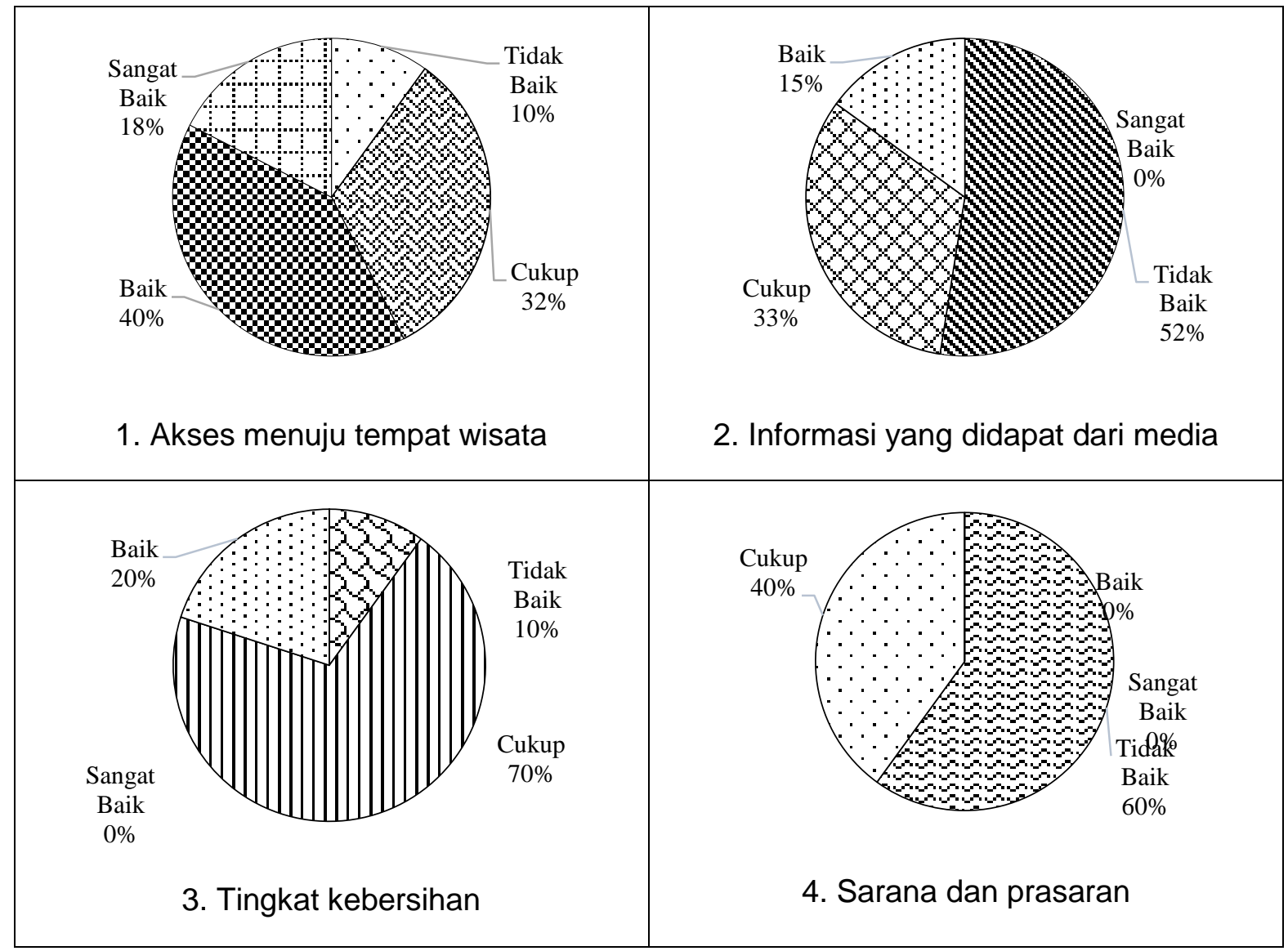




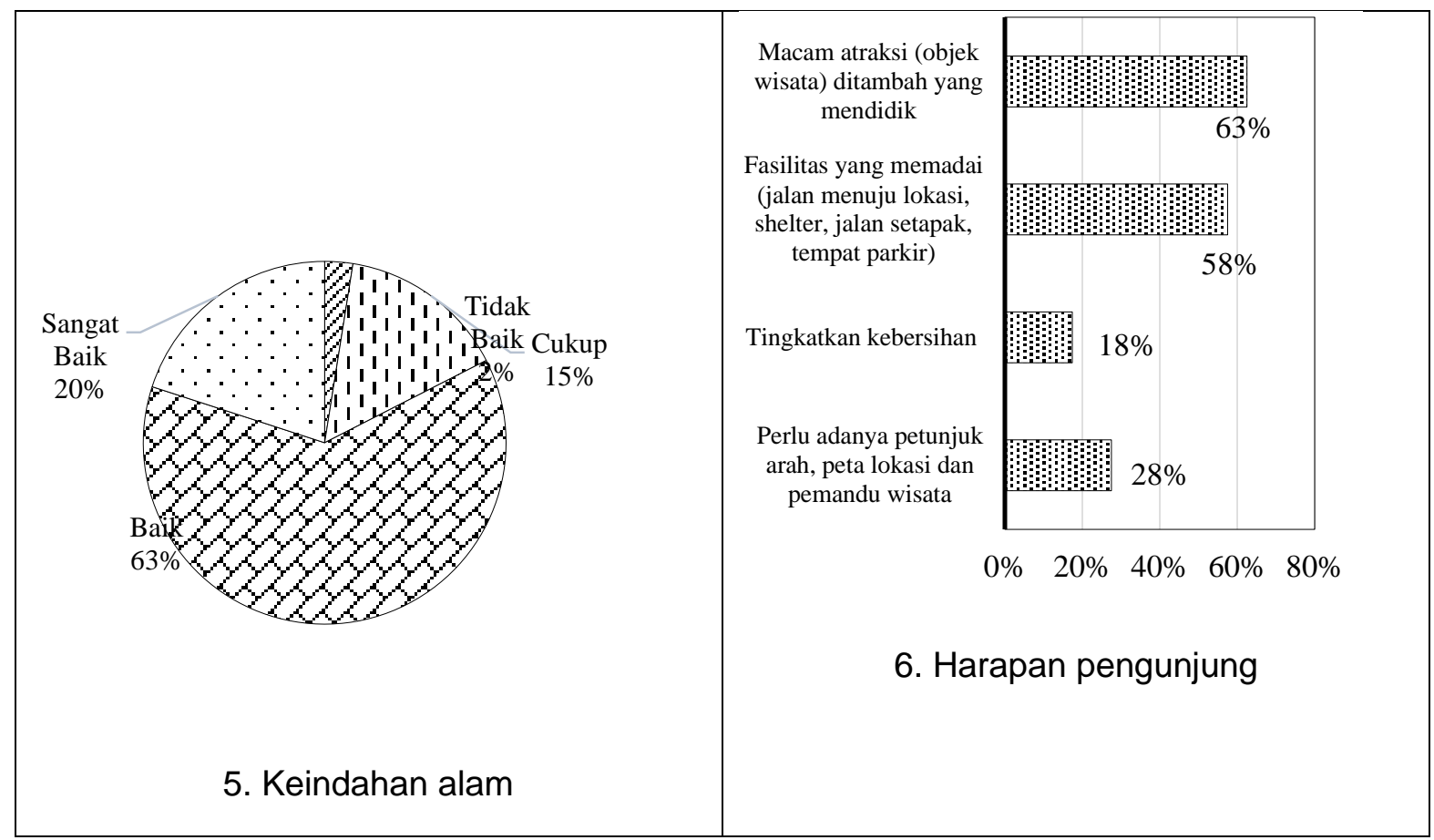

Gambar 1. Penilaian pengunjung terhadap KHDTK Gunung Bromo

Figure 1. Visitor assessment of KHDTK Gunung Bromo

\section{B. Analisis Daerah Operasi Obyek dan Daya Tarik Wisata Alam (ADO-ODTWA)}

Hasil penilaian potensi ODTWA kawasan KHDTK Gunung Bromo disajikan pada Tabel 2, yang merupakan indeks dari hasil penilaian tiap-tiap kriteria. ODTWA merupakan komponen sistem kepariwisataan yang terpenting, menjadi motivator utama perjalanan wisata dan inti dari produk wisata. Obyek dan daya tarik wisata adalah segala sesuatu yang memiliki keunikan, keindahan, dan nilai yang berupa keanekaragaman kekayaan alam, budaya, dan hasil buatan manusia yang menjadi sasaran atau tujuan kunjungan wisatawan (Gunawan 2000).

Tabel 2. Hasil penilaian kriteria potensi ODTWA di KHDTK Gunung Bromo

Table 2. Results of assessment of potential ODTWA criteria in KHDTK Gunung Bromo

\begin{tabular}{llccc}
\hline \multicolumn{1}{c}{ No Kriteria Penilaian } & & \multicolumn{3}{c}{ Nilai } \\
\cline { 3 - 5 } & & Nilai & $\begin{array}{c}\text { Indeks nilai } \\
\text { potensi }\end{array}$ & Klasifikasi \\
\hline 1 & Daya tarik ODTWA berbentuk darat & 1020 & $17 \%$ & Sedang \\
2 & Potensi pasar & 875 & $15 \%$ & Tinggi \\
3 & Kadar hubungan/ aksesibilitas & 600 & $10 \%$ & Sedang \\
4 & Kondisi sekitar kawasan & 900 & $15 \%$ & Sedang \\
5 & Pengelolaan dan pelayanan & 120 & $2 \%$ & Rendah \\
6 & Iklim & 400 & $7 \%$ & Tinggi \\
7 & Akomodasi & & $1 \%$ & Sedang \\
8 & Sarana dan prasarana penunjang & 60 & $1 \%$ & Rendah
\end{tabular}




\begin{tabular}{|c|c|c|c|}
\hline 9 Ketersediaan air bersih & 810 & $14 \%$ & Tinggi \\
\hline 10 Hubungan dengan obyek wisata di sekitarnya & 40 & $1 \%$ & Sedang \\
\hline 11 Keamanan & 575 & $10 \%$ & Tinggi \\
\hline 12 Daya dukung kawasan & 360 & $6 \%$ & Tinggi \\
\hline 13 Pengaturan pengunjung & 30 & $1 \%$ & Rendah \\
\hline 14 Pemasaran & 60 & $1 \%$ & Sedang \\
\hline 15 Pangsa pasar & 180 & $3 \%$ & Sedang \\
\hline Jumlah & 6040 & $100 \%$ & Sedang \\
\hline
\end{tabular}

Obyek dan daya tarik wisata merupakan pertimbangan pertama dalam melakukan perjalanan. Tanpa keberadaan obyek dan daya tarik wisata tidak akan ditemui pelayanan penunjang kepariwisataan lainnya (Spillane 1985). Berdasarkan hasil penilaian kriteria diketahui bahwa kawasan KHDTK Gunung Bromo memiliki klasifikasi sedang (6.040) yang mengindikasikan bahwa kawasan ini memiliki potensi dan layak untuk dikembangkan, namun memiliki beberapa hambatan dan kendala untuk dikembangkan sebagai destinasi ekowisata. Berdasarkan hasil penilaian ADO-ODTWA kawasan dapat dikembangkan dengan persyaratan tertentu yang memerlukan perhatian dan pembenahan lebih lanjut terutama untuk aspek yang nilainya rendah antara lain perlu meningkatkan sarana dan prasarana, pengelolaan dan pelayanan, serta pengaturan pengunjung.

Potensi pasar KHDTK Gunung Bromo tergolong tinggi (Tabel 2) hal ini karena kepadatan penduduk di Provinsi Jawa Tengah lebih besar dari $600 \mathrm{jiwa} / \mathrm{km}^{2}$. Menurut data Badan Pusat Statistika Provinsi Jawa Tengah (2019) kepadatan penduduk Provinsi Jawa Tengah tahun 2018 sebesar 1.020 jiwa/ $\mathrm{km}^{2}$. Iklim di KHDTK Gunung Bromo juga memiliki nilai yang tinggi sehingga iklim sangat mendukung untuk kegiatan wisata. Kondisi iklim dan cuaca merupakan faktor yang mempengaruhi permintaan wisata antara lain dalam menentukan pilihan tujuan atau jenis kegiatan yang akan dilakukan wisatawan (Matzarakis 2006; Amelung et al. 2007)

\section{Strategi Pengembangan Wisata Alam}

Strategi pengembangan wisata alam KHDTK Gunung Bromo menggunakan analisis SWOT (Rangkuti 2000). Analisis lingkungan internal dilakukan pada aspek manajemen, pemasaran, keuangan/akuntansi, penelitian dan pengembangan serta sistem informasi manajemen (David 2006, Fahmi 2015). Hasil analisis lingkungan internal diperoleh lima kekuatan dan delapan kelemahan sebagaimana pada Tabel 3. Selisih total nilai kekuatan dengan kelemahan adalah sebesar positif 0,136 . Hal ini menunjukan bahwa memiliki faktor kekuatan yang lebih besar dibandingkan dengan faktor kelemahan.

Tabel 3 Faktor kekuatan dan kelemahan wisata alam di KHDTK Gunung Bromo Table 3 Factors strengths and weaknesses of nature-based tourism in KHDTK Gunung Bromo

\begin{tabular}{|c|c|c|c|c|}
\hline Faktor Internal & Kekuatan & Nilai & Kelemahan & Nilai \\
\hline Manajemen & & & $\begin{array}{l}\text { 1. Belum ada dokumen rencana } \\
\text { pengeolaan sesuai status kawasan } \\
\text { 2. Belum tersedianya data potensi } \\
\text { kawasan secara menyeluruh }\end{array}$ & $\begin{array}{l}0,342 \\
0,351\end{array}$ \\
\hline Pemasaran & $\begin{array}{l}\text { 1. Lokasi yang strategis } \\
\text { (dekat dengan pusat kota) }\end{array}$ & 0,648 & $\begin{array}{l}\text { 3. Belum melakukan kegiatan } \\
\text { pemasaran wisata alam }\end{array}$ & 0,351 \\
\hline
\end{tabular}




\begin{tabular}{|c|c|c|c|c|}
\hline $\begin{array}{l}\text { Keuangan/ } \\
\text { akuntansi }\end{array}$ & & & $\begin{array}{l}\text { 4. Keterbatasan dana dan anggaran } \\
\text { 5. Belum terjalin kemitraan dalam } \\
\text { pengelolaan. }\end{array}$ & $\begin{array}{l}0,384 \\
0,320\end{array}$ \\
\hline $\begin{array}{l}\text { Produksi/ } \\
\text { operasi }\end{array}$ & $\begin{array}{l}\text { 2. Daya dukung kawasan } \\
\text { belum terlampaui untuk } \\
\text { pengembangan } \\
\text { ekowisata } \\
\text { 3. Memiliki potensi ODTWA } \\
\text { yang layak untuk } \\
\text { dikembangkan sebagai } \\
\text { wisata alam }\end{array}$ & $\begin{array}{l}0,657 \\
0,406\end{array}$ & $\begin{array}{l}\text { 6. Jumlah pengelola yang masih kurang. } \\
\text { 7. Fasilitas objek wisata yang kurang } \\
\text { memadai } \\
\text { 8. Kurangnya daya tarik atraksi buatan }\end{array}$ & $\begin{array}{l}0,240 \\
0,453 \\
0,350\end{array}$ \\
\hline $\begin{array}{l}\text { Penelitian/peng } \\
\text { embangan }\end{array}$ & $\begin{array}{l}\text { 4. Memiliki tenaga peneliti } \\
\text { dalam bidang kehutanan, } \\
\text { ekowisata, ekonomi dan } \\
\text { seni budaya }\end{array}$ & 0,608 & & \\
\hline $\begin{array}{l}\text { Sistem } \\
\text { informasi } \\
\text { manajemen }\end{array}$ & $\begin{array}{l}\text { 5. Pengelolaan data } \\
\text { informasi dan pencatatan } \\
\text { keuangan yang cukup } \\
\text { baik }\end{array}$ & 0,608 & & \\
\hline Total & Nilai kekuatan & 2,928 & Nilai kelemahan & 2,792 \\
\hline
\end{tabular}

Analisis lingkungan eksternal dilakukan pada aspek ekonomi; sosial, budaya, demografi, dan lingkungan; politik, pemerintah, dan hukum; teknologi; dan persaingan (David 2006). Hasil analisis lingkungan eksternal diperoleh lima peluang dan tiga ancaman sebagaimana pada Tabel 4. Hasil selisih nilai total peluang dengan ancaman adalah positif 0,369 . Nilai ini menunjukan bahwa memiliki peluang yang lebih besar dibandingkan ancaman sehingga diperlukan strategi untuk memanfaatkan peluang ini.

Tabel 4 Faktor peluang dan ancaman wisata alam di KHDTK Gunung Bromo Table 4 Factors of opportunity and threat of nature-based tourism in KHDTK Gunung Bromo

\begin{tabular}{|c|c|c|c|c|}
\hline $\begin{array}{l}\text { Faktor } \\
\text { Eksternal }\end{array}$ & Peluang & Nilai & Ancaman & Nilai \\
\hline Ekonomi & $\begin{array}{l}\text { 1. Kondisi perbankan nasional yang } \\
\text { stabil }\end{array}$ & 0,398 & & \\
\hline $\begin{array}{l}\text { Sosial, } \\
\text { Budaya, } \\
\text { Demografi, } \\
\text { dan } \\
\text { Lingkungan }\end{array}$ & $\begin{array}{l}\text { 2. Tren konsumsi wisata back to } \\
\text { nature. } \\
\text { 3. Meningkatnya jumlah generasi usia } \\
\text { muda yang menyukai berwisata }\end{array}$ & $\begin{array}{c}0,841 \\
0,841\end{array}$ & $\begin{array}{l}\text { 1. Sampah dan vandalisme } \\
\text { 2. Potensi konflik pemanfaatan } \\
\text { ruang dengan masyarakat } \\
\text { penggarap }\end{array}$ & $\begin{array}{l}0,917 \\
0,926\end{array}$ \\
\hline $\begin{array}{l}\text { Politik, } \\
\text { Pemerintah, } \\
\text { dan Hukum }\end{array}$ & $\begin{array}{l}\text { 4. Dukungan para pihak dalam } \\
\text { pengembangan wisata }\end{array}$ & 0,561 & & \\
\hline Teknologi & $\begin{array}{l}\text { 5. Pesatnya kemajuan } \\
\text { perkembangan internet dan } \\
\text { telepon seluler di masyarakat }\end{array}$ & 0,728 & & \\
\hline Persaingan & & & $\begin{array}{l}\text { 3. Tingkat persaingan usaha } \\
\text { wisata di sekitar lokasi }\end{array}$ & 1,157 \\
\hline Total & Nilai Peluang & 3,369 & Nilai Ancaman & 3,000 \\
\hline \multicolumn{5}{|c|}{$\begin{array}{l}\text { Berdasarkan hasil perhitungan total nilai dapat diketahui bahwa usaha wisata alam } \\
\text { KHDTK Gunung Bromo saat ini berada pada kuadran I (satu). Kuadran I (satu) merupakan } \\
\text { situasi yang sangat menguntungkan, memiliki peluang dan kekuatan sehingga dapat } \\
\text { memanfaatkan peluang yang ada. Strategi yang harus diterapkan dalam kondisi ini adalah } \\
\text { mendukung kebijakan pertumbuhan yang agresif (Rangkuti 2000). Hasil analisis matrik } \\
\text { SWOT menghasilkan empat tipe strategi yaitu Strategi SO (Strength-Opportunities), ST } \\
\text { (Strength-Threats), WO (Weaknesses-Oppourtunities), dan WT (Weaknesses-Threats) } \\
\text { sebagaimana pada Gambar 1. Berdasarkan empat tipe strategi tersebut KHDTK Gunung } \\
\text { Bromo berada di kuadran I sehingga strategi utama adalah Strategi SO antara lain: }\end{array}$} \\
\hline
\end{tabular}


Mempertahankan potensi sumber daya hutan yang tinggi sebagai daya tarik wisata; mengembangkan produk wisata yang memiliki daya saing; kolaborasi pengelolaan dengan investor yang sejalan dengan ekowisata; dan melakukan kegiatan promosi secara intensif.

\begin{tabular}{|c|c|c|}
\hline Faktor Eksternal & $\begin{array}{l}\text { S: Strength (Kekuatan) } \\
\text { 1. Daya dukung kawasan belum } \\
\text { terlampaui untuk } \\
\text { pengembangan ekowisata } \\
\text { 2. Memiliki potensi ODTWA } \\
\text { yang layak untuk } \\
\text { dikembangkan sebagai } \\
\text { wisata alam } \\
\text { 3. Memiliki tenaga peneliti } \\
\text { dalam bidang kehutanan, } \\
\text { ekowisata, ekonomi dan seni } \\
\text { budaya } \\
\text { 4. Pengelolaan data informasi } \\
\text { dan pencatatan keuangan } \\
\text { yang cukup baik }\end{array}$ & $\begin{array}{l}\text { W: Weaknesses (Kelemahan) } \\
\text { 1. Belum ada dokumen rencana } \\
\text { pengeolaan sesuai status } \\
\text { kawasan } \\
\text { 2. Belum tersedianya data potensi } \\
\text { kawasan secara menyeluruh } \\
\text { 3. Belum melakukan kegiatan } \\
\text { pemasaran wisata alam } \\
\text { 4. Keterbatasan dana dan } \\
\text { anggaran } \\
\text { 5. Belum terjalin kemitraan dalam } \\
\text { pengelolaan. } \\
\text { 6. Jumlah pengelola yang masih } \\
\text { kurang. } \\
\text { 7. Fasilitas objek wisata yang } \\
\text { kurang memadai } \\
\text { 8. Kurangnya daya tarik atraksi } \\
\text { buatan }\end{array}$ \\
\hline $\begin{array}{l}\text { O: Opportunities (Peluang) } \\
\text { 1. Tren konsumsi wisata back to } \\
\text { nature. } \\
\text { 2. Kondisi perbankan nasional yang } \\
\text { stabil } \\
\text { 3. Meningkatnya jumlah generasi usia } \\
\text { muda yang menyukai berwisata } \\
\text { 4. Dukungan para pihak dalam } \\
\text { pengembangan wisata } \\
\text { 5. Pesatnya kemajuan perkembangan } \\
\text { internet dan telepon seluler di } \\
\text { masyarakat }\end{array}$ & $\begin{array}{l}\text { Strategi S-O } \\
\text { 1. Mempertahankan potensi } \\
\text { sumber daya hutan yang } \\
\text { tinggi sebagai daya tarik } \\
\text { wisata } \\
\text { 2. Kolaborasi pengelolaan } \\
\text { dengan investor yang sejalan } \\
\text { dengan ekowisata } \\
\text { 3. Mengembangkan produk } \\
\text { wisata yang memiliki daya } \\
\text { saing } \\
\text { 4. Melakukan kegiatan promosi } \\
\text { secara intensif }\end{array}$ & $\begin{array}{l}\text { Stategi W-O } \\
\text { 1. Menyusun rencana } \\
\text { pengelolaan } \\
\text { 2. Bekerjasama dengan investor } \\
\text { yang sejalan dengan ekowisata } \\
\text { 3. Mengembangkan sarana } \\
\text { prasarana wisata yang sesuai } \\
\text { dengan harapan wisatawan } \\
\text { 4. Memperbaiki manajemen serta } \\
\text { meningkatkan kuantitas dan } \\
\text { kualitas pengelola }\end{array}$ \\
\hline $\begin{array}{l}\text { T: Threats (Ancaman) } \\
\text { 1. Sampah dan vandalisme } \\
\text { 2. Potensi konflik pemanfaatan ruang } \\
\text { dengan masyarakat penggarap } \\
\text { 3. Tingkat persaingan usaha wisata di } \\
\text { sekitar lokasi }\end{array}$ & $\begin{array}{l}\text { Strategi S-T } \\
\text { 1. Memanfaatkan seluruh } \\
\text { sumber daya yang ada untuk } \\
\text { meningkatkan kualitas produk } \\
\text { wisata } \\
\text { 2. Membangun kerja tim yang } \\
\text { efektif dan efisien } \\
\text { 3. Membangun kerjasama } \\
\text { dengan masyarakat dalam } \\
\text { mengelola wisata }\end{array}$ & $\begin{array}{l}\text { Strategi W-T } \\
\text { 1. Memperkuat kerjasama dengan } \\
\text { berbagai stakeholder untuk } \\
\text { meminimalkan kelemahan dan } \\
\text { mengurangi ancaman terhadap } \\
\text { wisata alam KHDTK Gunung } \\
\text { Bromo }\end{array}$ \\
\hline
\end{tabular}

Gambar 2 Matrik SWOT pengembangan wisata alam di KHDTK Gunung Bromo Figure 2 SWOT matrix for nature-based tourism developmen in KHDTK Gunung Bromo

\section{KESIMPULAN}

Hasil penelitian menunjukan penilain pengunjung terhadap akses menuju lokasi dinilai sangat baik (40\%) dan sangat baik (17\%); tingkat kebersihan dinilai cukup (70\%) dan baik $(20 \%)$; sarana prasarana dinilai tidak baik $(60 \%)$; keindahan alam dinilai baik $(63 \%)$ dan sangat baik (20\%). Hasil nilai potensi ADO-ODTWA sebesar 6.050 termasuk klasifikasi nilai sedang. Adapun prioritas strategi pengembangan wisata alam di KHDTK Gunung Bromo yaitu: Mempertahankan potensi sumber daya hutan yang tinggi sebagai daya tarik 
wisata; mengembangkan produk wisata yang memiliki daya saing; kolaborasi pengelolaan dengan investor yang sejalan dengan ekowisata; dan melakukan kegiatan promosi secara intensif.

\section{DAFTAR PUSTAKA}

David, F.R. (2006). Manajemen Strategis. Ed ke-10. Budi IS, penerjemah. Jakarta: Salemba Empat. Terjemahan dari: Strategic Management.

Amelung, B., S. Nicholls, dan D. Viner. (2007). Implications of Global Climate Change for Tourism Flows and Seasonality. Travel Research 45 (2007): 285-296.

Fahmi, I. (2015). Manajemen Strategis: Teori dan Aplikasi. Bandung: Alfabeta.

Fandeli, C, Muhammad. (2009). Prinsip-Prinsip Dasar Mengkonservasi Lanskap. Yogyakarta. Gadjah Mada University Press.

Gold, S.M. (1980). Recreation Planning and Design. New York: Mc Graw-Hill Book Company.

Gunawan, M.P. (2003). Kebijakan Pemerintah Tentang Interpretasi Wisata Alam dan Ekowisata. Dalam: Pengembangan Interpretasi Wisata Alam dan Ekowisata. Prosiding: Bogor, 9 Desember 2003. Bogor: Studio Rekreasi Alam departemen Konservasi Sumberdaya Hutan. Fakultas Kehutanan. Institut Pertanian Bogor. HIm 1-6.

Karyono, Subarudi. (2001). Study Perbandingan Nilai Produk Jasa Wisata dan Kayu Pada Hutan Produksi di Jawa Barat. Jurnal Sosial Ekonomi. www. puslitsosekhut.web.id/download.php?page=publikasi\&su. [20 Agustus 2001]

Korah, H.L. (1995). Analisis Belanja Wisatawan dan Pengaruhnya terhadap Aktivitas Ekonomi Masyarakat (studi Kasus Manado-Minahasa). Program Pascasarjana. KPK IPB-UNSRAT Manado.

Kusumastuti, E. (2018). UNS Kelola KHDTK Gunung Bromo Untuk Pendidikan. Retrieved from http://www.suarakarya.id/detail/81108/UNS-Kelola-KHDTK-Gunung-Bromo-UntukPendidikan

Kumar R. 1999. Research Methodology. London: Sage.

Matzarakis, A., (2006). Tourism and Hospitality Planning and Development. Weather-and Climate-Related Information for Tourism 3 (2), pp. 101.

Nugroho. (2017). Analisis Pengelolaan Kawasan Hutan dengan Tujuan Khusus (Studi Kasus Hutan Pendidikan dan Latihan Gunung Walat). Journal of Env. Engineering \& Waste Management, Vol. 2, No. 2, Oktober 2017: 51-59

Nurfatriani F, Efida, Y.S. (2003). Pengelolaan Ekowisata Berbasis Masyarakat Lokal. Buletin Penelitian dan Pengembangan Kehutanan IV (1): 31-39.

Rangkuti, F. (2000). Analisis SWOT Teknik Membedah Kasus Bisnis. Jakarta : PT Gramedia Pustaka Utama,.

Vengesayi, S. (2003). A conceptual model of toudestination competitiveness and attractiveness. AnzmConference proceedings; Des 1-3. Adelaide. Australia. 